HETEROCYCLES, Vol. 70, 2006, pp. 207 - 221. (C) The Japan Institute of Heterocyclic Chemistry

Received, 19th May, 2006, Accepted, 10th July, 2006, Published online, 11th July, 2006. COM-06-S(W)5

\title{
CYCLOADDITION REACTIONS OF 1-AZA- AND
}

\section{1,3-DIAZAAZULENIUM 1-METHYLIDES ${ }^{\dagger}$}

\section{Hiroyuki Fujii, ${ }^{\# *}$ Izumi Kawano, Kaoru Iwafuji, Yoshiyuki Sawae, Kentaro Nagamatsu, and Noritaka Abe*}

Department of Chemistry, Faculty of Science, Yamaguchi University, Yoshida, Yamaguchi 753-8512, Japan

${ }^{\#}$ Science Research Center, Yamaguchi University, Yoshida, Yamaguchi 753-8512, Japan

\begin{abstract}
Chloro-, 2-methoxy-, and 2-amino-1-azaazulenium 1-methylides and 1,3-diazaazulenium 1-methylide were generated by the treatment of the corresponding 1-trimethylsilylmethyl-1-azaazulenium triflates and 1-trimethylsilylmethyl-1,3-diazaazulenium triflate with CsF; the triflates were prepared from the corresponding 1-azaazulenes and 1,3-diazaazulene with trimethylsilylmethyl triflate. The 1,3-dipolar cycloadditions of the 2-chloro-1-azazaazulenium 1-methylide, prepared in situ, with acetylenic esters gave 2a-azabenz $[c d]$ azulene derivatives and 3a-azacyclopenta $[a]$ naphthalene derivatives as major products, whereas 2-piperizino-1-azaazulenium 1-methylide underwent extended dipolar cycloaddition with acetylenic esters and afforded $9 b$-azacyclopent $[a]$ azulene derivatives as major products.
\end{abstract}

\section{INTRODUCTION}

Heteroaromatic $N$-ylides ${ }^{1-3}$ and heteroaromatic $N$-imines ${ }^{4-8}$, which are highly useful synthetic intermediate for the construction of fused heterocycles via 1,3-dipolar cycloaddition reaction. ${ }^{9,10}$ We previously reported about the synthesis and reactions of 1-azaazulene $N$-imine (1) where interesting dipolar cycloadditions were observed. ${ }^{11}$ Although a non-alternant heteroaromatic $N$-ylide has large potential for the construction of new heterocyclic nuclei, which have an interesting function such as bioactivity and

\footnotetext{
${ }^{\dagger}$ Dedicated to Professor Steven M. Weinreb occasion of his 65th birthday.
} 
dye, the investigation was rarely reported. Recently, we communicated the generation of 1-azaazulenium 1-methylides $(\mathbf{2 a}, \mathbf{c}){ }^{12} \quad$ For the development of azaazulene chemistry ${ }^{13}$ and for an interest in the construction of new fused heterocycles, we advanced the investigation to the reactions of 1-azaazulenium 1-methylides, and we wish report the full detail herein.

\section{RESULTS AND DISCUSSION}

Generation of azomethine ylide by desilylation from $\alpha$-silyliminium salts is interesting and a facile route to pyrrolidines and pyrroles was reported recently. ${ }^{14}$ Because $N$-alkylations of 1 -azaazulene are known, ${ }^{15,16}$ we intend to make a 1 -azaazulenium 1-methylide by $N$-trimethylsilylmethylation of 1-azaazulene followed by desilylation. Thus 2-chloro-1-azaazulene (3a) was treated with trimethylsilylmethyl triflate in dichloromethane for $48 \mathrm{~h}$, and 2-chloro-1-trimethylsilylmethyl-1azaazulenium triflate (4a) was obtained in $87 \%$ yield. The structure was deduced on the basis of the spectroscopic data as well as elemental analyses. In the ${ }^{1} \mathrm{H}$ NMR spectrum of $\mathbf{4 a}$, rather low resonated proton signals were seen at $\delta 7.68(\mathrm{~s}, \mathrm{H}-3), 8.51$ (dd, $J 10.1$ and 9.8, H-7), 8.60 (dd, $J 10.2$ and 9.9, H-5), 8.71 (dd, $J 10.2$ and 9.8, H-6), 9.06 (d, $J$ 9.9, H-4), and 9.47 (1H, d, $J$ 10.1, H-8) together with silylmethyl signals at $\delta 0.14(9 \mathrm{H}, \mathrm{s})$ and a methylene signal at $\delta 4.59(2 \mathrm{H}, \mathrm{s})$. This suggests that the cationic charge on $\mathbf{4 a}$ delocalized to 1-azaazulene ring.

Similar treatment of the 1-azaazulenes (3b-3e) with trimethylsilylmethyl triflate in dichloromethane for 48 h gave $\mathbf{4 b}(90 \%), \mathbf{4 c}(92 \%), \mathbf{4 d}(96 \%)$, and $\mathbf{4 e}(64 \%)$, respectively.

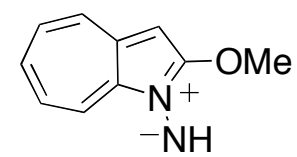

1

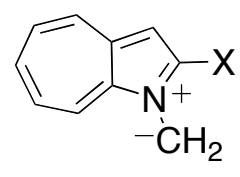

2a $: X=\mathrm{Cl}$
2b: $: X=\mathrm{OMe}$
2c $: X=$ piperidino
2d $: X=$ ethylamino
2e $: X=$ amino

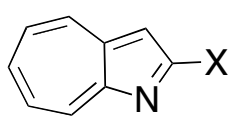

3a: $\mathrm{X}=\mathrm{Cl}$

3b: $: \mathrm{X}=\mathrm{OMe}$

3c $: X=$ piperidino

3d : $X=$ ethylamino

3e : $\mathrm{X}=$ amino

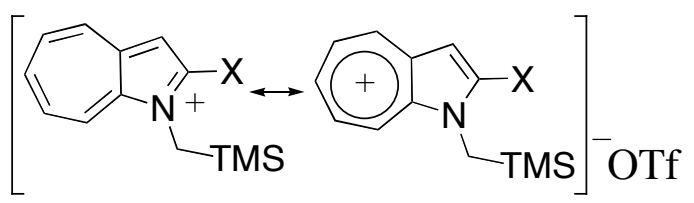

4a: $\mathrm{X}=\mathrm{Cl}$

4b: $: \mathrm{X}=\mathrm{OMe}$

$4 \mathbf{c}: \mathrm{X}=$ piperidino

4d : $X=$ ethylamino

4e $: X=$ amino

Desilyation of the salt (4) would produce the ylide (2). To consider the character of 1-azaazulenium 1-methylides, we carried out the molecular orbital calculation of 2-substituted 1-azaazulenium 1-methylides (2a,c) by Spartan'02 with RHF/6-31G* basis set. ${ }^{17}$ Calculated bond lengths and electron densities were shown in Figure 1. From the consideration of bond lengths, 2c would have a character as for heptafulvene and amidinium ion, where large bond alternation than that of $\mathbf{2 a}$ is seen. Atomic charges at C-2, C-8, and C-8a are nearly equal on $\mathbf{2 a}$, whereas C-2 is highly positive on $\mathbf{2 c}$. 


\section{Bond lengths}

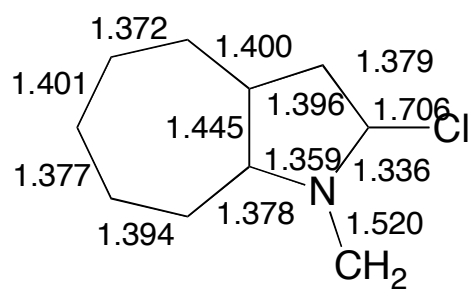

2a

\section{Atomic charges}

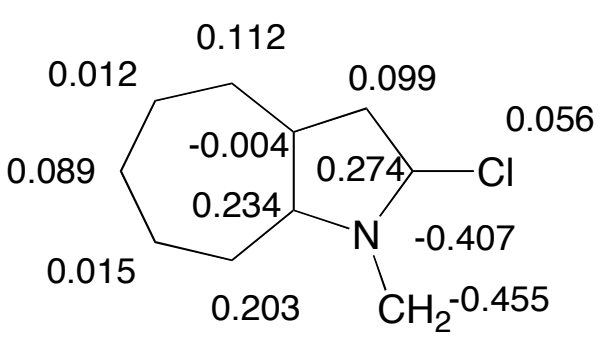

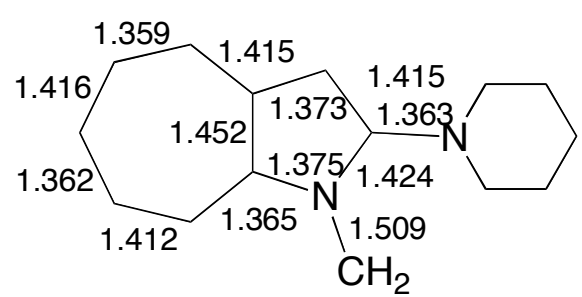

$2 c$

Figure 1. Bond lengths ( $\AA$ ) (upper) and atomic charges (lower) of 1-azaazulenium 1-methylides. Calculations were performed by Spartan'02 (RHF / 6-31G*).

1-Azaazulenium 1-methylide (2a) could not be obtained by the treatment of $\mathbf{4 a}$ with pottasium carbonate or tetrabutylammonium fluoride. It was very difficult to isolate a clear product. It is known that pyridinium methylides generated by the treatment of $N$-(trimethylsilylmethyl)pyridinium triflates with CsF. ${ }^{18-20}$ Therefore, the desilylation of $\mathbf{4}$ with $\mathrm{CsF}$ or KF and the trapping experimrnts in the presence of acetylenic esters were carried out as follows. The treatment of $\mathbf{4 a}$ with CsF, dried before use, in the presence of dimethyl acetylenedicarboxylate (DMAD) in acetonitrile at $0{ }^{\circ} \mathrm{C}$ for $6 \mathrm{~h}$ gave 2a-azabenz $[c d]$ azulene derivatives (5aa) (5\%), 3a-azacyclopenta $[a]$ naphthalene (6aa) (7\%), and 9b-azacyclopent $[a]$ azulene derivatives (7) (3\%) (Run 1). The yield was slightly improved at elevated reaction temperature and 5aa (8\%) and 6aa (11\%) was obtained, instead 7 was not obtained (Run 2). When the reaction was performed in $N, N$-dimethylacetoamide (DMA), yields were slightly change and the compounds (5aa) (5\%), (6aa) (7\%), (7) (2\%), and (8) (0.4\%) were obtained (Run 3). It is considered that $\mathbf{8}$ would be a secondary cycloadduct from the reaction of $\mathbf{5}$ and/or $\mathbf{7}$ with DMAD. Compounds (5) and (7) were expected to be precursors of 8 . Indeed 7 reacted with DMAD to give 8 in $12 \%$ yield. But its yield was not good. During the process from 7 to 8 , dehydrogenation needs to proceed. We previously reported that the reaction of $\mathbf{1 0}$ with DMAD gave cycloadduct (11). ${ }^{21}$ 
Therefore, we thought their yields would be improved somewhat higher when cycloaddition was carried out in the presence of oxidants such as tetrachloro-p-benzoquinoneone (chloranil) or 2,3-dichiloro-5,6-dicyano-p-benzoquinone (DDQ). Thus 4a was treated with CsF and DMAD in acetonitrile at room temperature for $22 \mathrm{~h}$, then the mixture was treated with chloranil for $24 \mathrm{~h}$ gave 5aa (7\%) and 6aa (19\%) (Run 5). In this case, the yields of 5aa and 6aa were slightly improved, but 7 and 8 were not obtained. As shown as above, 7 could undergo cycloaddition.<smiles>[X]c1cc([Z10])c2ccccc2c1</smiles>

5aa : $\mathrm{X}=\mathrm{Cl}, \mathrm{E}_{1}=\mathrm{E}_{2}=\mathrm{CO}_{2} \mathrm{Me}$ 5ba : $\mathrm{X}=\mathrm{OMe}, \mathrm{E}_{1}=\mathrm{E}_{2}=\mathrm{CO}_{2} \mathrm{Me}$

5ca : $\mathrm{X}=$ piperidino, $\mathrm{E}_{1}=\mathrm{E}_{2}=\mathrm{CO}_{2} \mathrm{Me}$ 5ab : $\mathrm{X}=\mathrm{Cl}, \mathrm{E}_{1}=\mathrm{CO}_{2} \mathrm{Me}, \mathrm{E}_{2}=\mathrm{H}$<smiles>[Z10]c1cn2c([X])cc3ccccc3c2c1[Z17]</smiles>

6aa : $\mathrm{X}=\mathrm{Cl}, \mathrm{E}_{1}=\mathrm{E}_{2}=\mathrm{CO}_{2} \mathrm{Me}$ 6ba : $\mathrm{X}=\mathrm{OMe}, \mathrm{E}_{1}=\mathrm{E}_{2}=\mathrm{CO}_{2} \mathrm{Me}$ 6ca : $\mathrm{X}=$ piperidino, $\mathrm{E}_{1}=\mathrm{E}_{2}=\mathrm{CO}_{2} \mathrm{Me}$ 6ab : $\mathrm{X}=\mathrm{Cl}, \mathrm{E}_{1}=\mathrm{CO}_{2} \mathrm{Me}, \mathrm{E}_{2}=\mathrm{H}$<smiles>COCc1c(C(=O)OC)c(C(=O)OC)cc2ccccc12</smiles>

8<smiles>COC/C(=C\C(C)=O)C1=C2C=CC=CC2C(C(=O)OC)=C(C(=O)OC)C1N1CCCCC1</smiles>

9<smiles>COC(=O)C1=C(C(=O)OC)N(C(C)=O)C=C(c2ccccc2)c2ccccc21</smiles>

10<smiles>COC(=O)c1c2c(-c3ccccc3)c3cccc4c(C(=O)OC)c(C(=O)OC)c(c1C(=O)OC)c-2c43</smiles>

11

Therefore, it is thought that 7 would consumed by the reaction with chloranil. Indeed, when $\mathbf{7}$ was treated with chloranil, 7 was disappeared but clear products were not obtained. As shown in Runs 5-8, a clear solvent effect was not obtained. Using excess molar of DMAD in the reaction improved the yields (Runs 10-13), and increasing of the yield of 8 was observed on the reaction at $0{ }^{\circ} \mathrm{C}$ (Run 12).

The structures of 5-7 were established on the basis of the spectroscopic data. In the ${ }^{1} \mathrm{H}$ NMR spectrum of 5aa, rather high-field resonated signals of seven-membered ring protons appeared at $\delta 4.95(\mathrm{H}-7), 5.28$ $(\mathrm{H}-8), 5.59(\mathrm{H}-9)$, and $5.72(\mathrm{H}-6)$, which have a large divergence of the coupling constants $\left(J_{5-6}=11.2\right.$, 
$J_{6-7}=7.8$, and $\left.J_{7-8}=12.8\right)$ showing the presence of the bond-alternation in the seven-membered ring, together with two $1 \mathrm{H}$ singlets, at $\delta 6.07(\mathrm{H}-1)$ and $7.36(\mathrm{H}-3)$, and two methyl signals. In the ${ }^{1} \mathrm{H}$ NMR

Table 1. Reactions of 1-azaazulenium methylides with reactive acetylenes

\begin{tabular}{|c|c|c|c|c|c|c|c|c|}
\hline Run & Reactant & Acetylene & Ratio & Oxidant & Reaction & conditions & & Products (Yield / \%) \\
\hline & & & & & Solvent & Temp. $/{ }^{\circ} \mathrm{C}$ & Time / h & \\
\hline 1 & $\mathbf{4 a}$ & DMAD & $1: 1.3$ & & $\mathrm{MeCN}$ & 0 & 6 & 5aa(5) 6aa (7) 7 (3) \\
\hline 2 & $4 \mathbf{a}$ & DMAD & $1: 1.0$ & & $\mathrm{MeCN}$ & reflux & 1 & $5 \mathbf{a a}(8) \mathbf{6 a a}(11)$ \\
\hline 3 & $\mathbf{4 a}$ & DMAD & $1: 1.3$ & & DMA & 0 & 6 & $\mathbf{5 a a}(10) \mathbf{6 a a}(18) 7(2) \mathbf{8}(0.4)$ \\
\hline 4 & $4 \mathbf{a}$ & DMAD & $1: 1.5$ & & THF & $-90 \rightarrow 10$ & 51 & $5 \mathbf{a a}(6) 6 \mathbf{a a}(15)$ \\
\hline 5 & $\mathbf{4 a}$ & DMAD & $1: 2.4$ & chloranil & $\mathrm{MeCN}$ & $\mathrm{rt}$ & 22 & $5 \mathbf{a a}(9) 6 \mathbf{a a}(17)$ \\
\hline 6 & $\mathbf{4 a}$ & DMAD & $1: 2.4$ & chloranil & dioxane & $\mathrm{rt}$ & 21 & $\mathbf{5 a a}(8) \mathbf{6 a a}(22)$ \\
\hline 7 & $\mathbf{4 a}$ & DMAD & $1: 2.4$ & chloranil & $\mathrm{DMF}$ & $\mathrm{rt}$ & 22 & $5 \mathbf{a a}(7) 6 \mathbf{a a}(24)$ \\
\hline 8 & $4 \mathbf{a}$ & DMAD & $1: 1.5$ & chloranil & DMSO & $\mathrm{rt}$ & 24 & $5 \mathbf{a a}(8) \mathbf{6 a a}(20)$ \\
\hline 9 & $\mathbf{4 a}$ & DMAD & $1: 1.5$ & DDQ & $\mathrm{MeCN}$ & $\mathrm{rt}$ & 22 & $5 \mathbf{a a}(10) \mathbf{6 a a}(13)$ \\
\hline 10 & $\mathbf{4 a}$ & DMAD & $1: 5$ & chloranil & $\mathrm{MeCN}$ & $\mathrm{rt}$ & 22 & $5 \mathbf{a a}(10) \mathbf{6 a a}(31)$ \\
\hline 11 & $\mathbf{4 a}$ & DMAD & $1: 5$ & chloranil & DMA & $\mathrm{rt}$ & 22 & $5 \mathbf{a a}(10) \mathbf{6 a a}(29)$ \\
\hline 12 & $\mathbf{4 a}$ & DMAD & $1: 5$ & chloranil & $\mathrm{MeCN}$ & 0 & 22 & $5 \mathbf{a a}(23) \mathbf{6 a a}(27) \mathbf{8}(6)$ \\
\hline 13 & $\mathbf{4 a}$ & DMAD & $1: 10$ & chloranil & $\mathrm{MeCN}$ & $\mathrm{rt}$ & 22 & 5aa(23) 6aa(32) \\
\hline 14 & $4 b$ & DMAD & $1: 1.5$ & & $\mathrm{MeCN}$ & $\mathrm{rt}$ & 20 & $5 \mathbf{b a}(7) 6 \mathbf{b a}(1) 7(14)$ \\
\hline 15 & $4 b$ & DMAD & $1: 3$ & chloranil & $\mathrm{MeCN}$ & $\mathrm{rt}$ & 22 & $\mathbf{6 b a}(8)$ \\
\hline 16 & $4 c$ & DMAD & $1: 2$ & & DMA & 0 & 6 & $7(8)$ \\
\hline 17 & $4 c$ & DMAD & $1: 2$ & & DMA & 0 & 12 & $7(10) 9(1.5)$ \\
\hline 18 & $4 c$ & DMAD & $1: 1.3$ & & $\mathrm{MeCN}$ & 0 & 22 & $7(22)$ \\
\hline 19 & $4 c$ & DMAD & $1: 1.3$ & chloranil & $\mathrm{MeCN}$ & $\mathrm{rt}$ & 22 & No distinct product \\
\hline 20 & $4 d$ & DMAD & $1: 1.3$ & & DMA & $\mathrm{rt}$ & 6 & No distinct product \\
\hline 21 & $4 e$ & DMAD & $1: 1.3$ & & $\mathrm{MeCN}$ & $\mathrm{rt}$ & 24 & No distinct product \\
\hline 22 & $4 \mathbf{a}$ & MP & $1: 1.4$ & chloranil & $\mathrm{MeCN}$ & $\mathrm{rt}$ & 21 & $\mathbf{6 a b}(3)$ \\
\hline $23^{\mathrm{a}}$ & $\mathbf{4 a}$ & MP & 1: 1.3 & & DMA & $\mathrm{rt}$ & 60 & $\mathbf{5 a b}(2) \mathbf{6} \mathbf{a b}(4)$ \\
\hline 24 & $4 d$ & MP & $1: 1.5$ & & $\mathrm{MeCN}$ & $\mathrm{rt}$ & 24 & No distinct product \\
\hline $25^{\mathrm{a}}$ & $4 \mathbf{a}$ & EB & $1: 1.3$ & & DMA & $\mathrm{rt}$ & 144 & No distinct product \\
\hline 26 & $4 \mathbf{a}$ & EB & $1: 2$ & chloranil & $\mathrm{MeCN}$ & reflux & 2 & No distinct product \\
\hline
\end{tabular}

a 0.1 Equivalent molar of $\mathrm{Yb}\left(\mathrm{CF}_{3} \mathrm{SO}_{3}\right)_{3}$ was used as catalyst. 

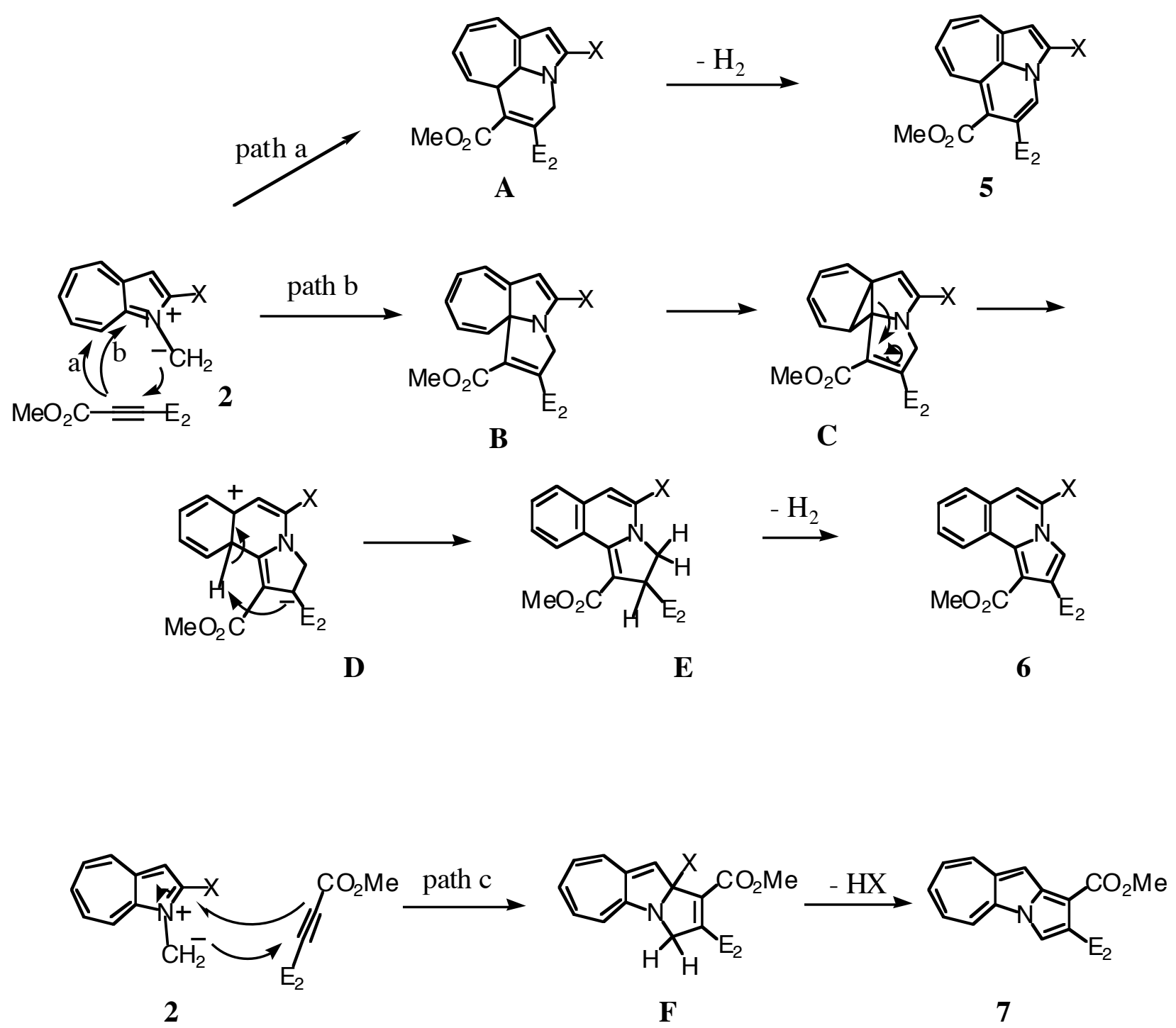

Scheme 1

spectrum of 6aa, two $1 \mathrm{H}$ singlets, at $\delta 7.06(\mathrm{H}-5)$ and $8.12(\mathrm{H}-3)$, and protons assignable to benzene ring were seen at $\delta 7.14-7.56(\mathrm{~m}, \mathrm{H}-6,7$, and 8) and $8.19(\mathrm{~d}, J$ 8.0, H-9) together with two methyl singlets. The structures of 5aa and 6aa were confirmed by X-Ray crystallographic analysis, and the results were previously reporetd. ${ }^{12}$

When 2-methoxy-1-trimethylsilylmethyl-1-azaazulenium triflate (4b) was treated with CsF and DMAD at room temperature for $20 \mathrm{~h}$, compounds (5ba, 6ba, and 7) were obtained in 7\%, 1\%, and 14\% yields, respectively (Run 14).

Reaction of 2-piperidino-1-trimethylsilylmethyl-1-azaazulenium triflate (4c) with CsF and DMAD in DMA gave $7(10 \%)$ and $9(1.5 \%)$, and the rearrangement product (6ca) was not obtained (Run 17). It seems that using longer reaction time improved the yield, and the yield of 7 increased to $22 \%$ (Run 18). Using of cloranil again resulted in disappearance of 7 (Run 19). 
When KF was used as a desilylation reagent of $\mathbf{4 a}$ in the presence 18-crown-6-ether, the cycloadducts (5aa and 6aa) were obtained in only trace yields.

Reactions of $\mathbf{4 d}$ and $\mathbf{4 e}$ with $\mathrm{CsF}$ and DMAD gave no distinct product (Runs 16-18). These results were different from the case of 1-amino-2-alkylamino- and 1,2-diamino-1-azaazulenium salts with base and reactive acetylenes, where cycloaddition was observed. ${ }^{22}$

For the examination of regioselectivity in the cycloaddition of $\mathbf{2}$ to acetylenes,, we investigate the reaction of 2 with methyl propiolate (MP) and ethyl butynolate (EB) as reactive acetylenes. When 4a was treated with MP in the presence of $\mathrm{CsF}$ in acetonitrile for $21 \mathrm{~h}$ at room temperature, followed by treatment with chloranil, 6ab was obtained in 3\% yield (Run 22). For expecting to improve the reaction by addition of Lewis acid, the reaction of $\mathbf{4 a}$ with $\mathrm{MP}$ in the presence of $\mathrm{Yb}\left(\mathrm{CF}_{3} \mathrm{SO}_{3}\right)_{3}$ was performed in DMA for $60 \mathrm{~h}$ at room temperature, but the yields were low and 5ab and $6 \mathbf{a b}$ were obtained in $2 \%$ and $4 \%$ yields (Run 23). In the ${ }^{1} \mathrm{H}$ NMR spectra of 5ab and 6ab, H-6 proton of 5ab and H-9 proton of $6 \mathbf{a b}$ were resonated at low field ( $\delta 7.16$ and $\delta 9.82$, respectively) compared with those of 5aa and 6aa $(\delta 5.72$ and $\delta 8.19$, respectively), which would be influenced by anisotropy of ester group situated at peri-position. It is known that the ester groups at C-5 of 5aa and at C-1 of 6aa were situated nearly perpendicular with rings, ${ }^{12}$ where steric repulsion between esters at C-4 and C-5 of 5aa and esters at between at C-1 and C-2 of 6aa would exist. Absence of the ester group at C-4 of 5aa and at C-2 of 6aa affords dissolution of the steric repulsion of the esters of 5ab and 6ab and, the esters at C-5 of 5aa and at C-1 of 6aa would be situated in co-planer with the rings. Reactions using EB was scarcely proceeded, and distinct product was not obtained (Runs 25 and 26).

Although yields were low, it is indicated that the reaction of $\mathbf{4 a}$ with MP proceeded regioselectively. A plausible formation mechanism of $\mathbf{5}, \mathbf{6}$, and $\mathbf{7}$ is shown in Scheme 1. From the consideration of the results (Table 1), it considered that the cycloaddition reaction was strongly affected by the functional group located at C-2 of the 1-azaazulenium 1-methylides (10). The results show that reaction of the 2-chloro-1-azazaazulenium 1-methylide gave 2a-azabenz $[\mathrm{cd}]$ azulene derivatives (5) and 3a-azacyclopenta $[a]$ naphthalene derivatives (6) as major products, whereas 2-piperizino-1-azazaazulenium 1-methylide afforded 9b-azacyclopent $[a]$ azulene derivative (7) as major product. Reaction of 2-methoxy-1-azazaazulenium 1-methylide gave 5, 6, and $\mathbf{7}$.

Next, for the investigation of streoselectivity in the cycloaddition of $\mathbf{2}$ to acetylenes, we examined the reaction of electron deficient olefins such as $N$-phenyl maleimide (PM) and $N$-methyl maleimide (MM). Treatment of 4a with CsF in the presence of PM in DMA for $1 \mathrm{~h}$ gave a complex mixture of yellow oils and a green compound. The structures of yellow oils could not be characterized because they were unstable. The green compound (12aa) was isolated in $31 \%$ yield by chromatography and the structure was deduced on the basis of the spectroscopic data. In the similar manner, reaction of $\mathbf{4 a}$ with $\mathbf{M M}$ and 
the reaction of 4c with PM gave 12ab (20\%) and 12ca (14\%), respectively. The obtained compounds (12aa-ca) were aromatized products and the stereoselectivity on the reaction could not be defined. In the reaction of $\mathbf{4 c}$ with $\mathrm{MM}$, the red oil $(\mathbf{1 3} \mathbf{c b})$ was obtained. In its ${ }^{1} \mathrm{H}$ NMR spectrum, methine and methylene protons were observed at $\delta 3.33$ (dd, 12.3 and 10.8, H-7), 3.57 (dd, $J 12.3$ and 6.3, H-7), and 4.79 (dd, $J 10.8$ and 6.3, H-7a). The seven-membered ring protons were appeared at $\delta 6.41$ (dd, $J 10.8$ and 8.3, H-3), 6.72 (dd, $J 12.1$ and 8.3, H-2), 7.02 (d, $J$ 10.8, H-4), and $8.28(1 \mathrm{H}, \mathrm{d}, J 12.1, \mathrm{H}-1)$. These data of 13cb suggested that there is bond-alternation, and $\mathbf{1 3} \mathbf{c b}$ is thought to have a heptafulvene structure. In this case, proton migration occurred and the stereoselectivity on the reaction could not be defined again.

For the comparison with the case of 1-azaazulene, we next synthesized 1-trimethylsilylmethyl-1,3diazaazulenium triflate (15) from 1,3-diazaazulene (14) in 79\% yield. In the similar manner as for 4, 3a,5-diazacyclopenta[ $[a]$ naphthalene derivative (15) was treated with CsF in the presence of DMAD for $24 \mathrm{~h}$ at room temperature, and only $\mathbf{1 6}$ was isolated in $9 \%$ yield. The reaction would proceed as a similar case to $\mathbf{4 b}$.

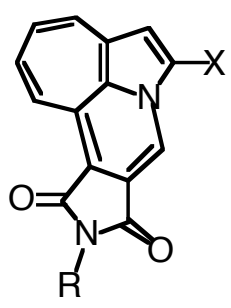

12aa : $\mathrm{X}=\mathrm{Cl}, \mathrm{R}=\mathrm{Ph}$

12ab : $\mathrm{X}=\mathrm{Cl}, \mathrm{R}=\mathrm{Me}$

12ca : $\mathrm{X}=$ piperidino, $\mathrm{R}=\mathrm{Ph}$

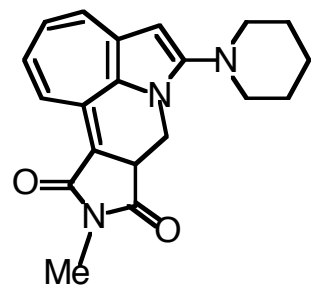

$13 \mathrm{cb}$

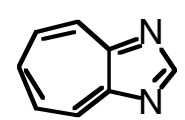

14

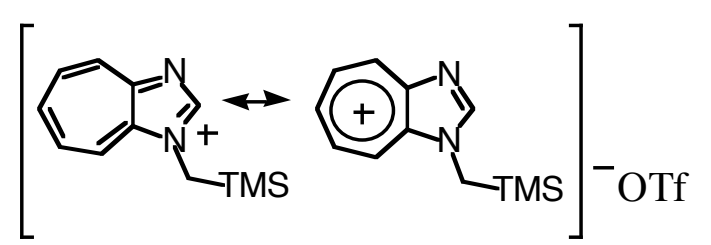

15

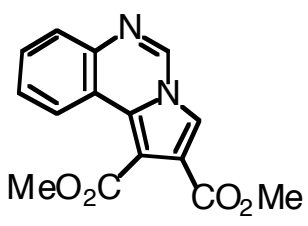

16

\section{CONCLUSION}

In summary, 1-azaazulenium 1-methylides (2) were trapped by acetylenic esters and three types of cycloadducts, 2a-azabenz $[c d]$ azulene derivatives, 3a-azacyclopent $[a]$ naphthalene derivatives, and $9 \mathrm{~b}$-azacyclopent $[a]$ azulene, were obtained. The selectivity of the reaction site on the cycloaddition of 1-azaazulenium 1-methylides was affected by the substituents at C-2 of $\mathbf{2}$. 


\section{EXPERIMENTAL}

Mps are measured using a Yanagimoto micro-melting apparatus and uncorrected. ${ }^{1} \mathrm{H}$ NMR spectra (including HH-COSY and CH-COSY NMR)) were recorded on a Bruker AVANCE 400S (400 MHz) and ${ }^{13} \mathrm{C}$ NMR spectra were recorded on a Bruker AVANCE 400S (100.6 MHz) using deuteriochloroform as a solvent with tetramethylsilane as an internal standard; $J$ values are recorded in Hz. IR spectra were recorded for $\mathrm{KBr}$ pellets on a Nicolet FT-IR Impact 410 unless otherwise stated. Electronic spectra were recorded with Shimadzu UV-1600PC spectrophotometer. MS spectra were taken with on a LC-MS Waters Integrity System. Elemental analyses were taken with a Perkin Elmer $2400 I I$. Kieselgel 60 was used for column chromatography and Kieselgel 60G was used for thin-layer chromatography.

\section{Synthesis of 1-trimethylsilylmethyl-1-azaazulenium triflates}

Typical procedure - Under argon atmosphere, a mixture of 2-chloro-1-azaazulene (3a) (2.062 g, 12.6 mmol), trimethylsilylmethyl triflate $(3.02 \mathrm{~mL}, 15.1 \mathrm{mmol})$ in dry $\mathrm{CH}_{2} \mathrm{Cl}_{2}(60 \mathrm{~mL})$ was stirred for $48 \mathrm{~h}$ at rt. To the mixture $\mathrm{Et}_{2} \mathrm{O}(200 \mathrm{~mL})$ was added, and stirring was continued for $5 \mathrm{~h}$. The precipitate was collected by filtration and 2-chloro-1-trimethylsilylmethyl-1-azaazulenium triflate (4a) (4.823 g, 87\%) was obtained.

4a: Yellow plates $\left(\mathrm{Et}_{2} \mathrm{O}-\mathrm{CH}_{2} \mathrm{Cl}_{2}\right)$, mp 143-144 ${ }^{\circ} \mathrm{C} ; \delta_{\mathrm{H}} 0.14(9 \mathrm{H}, \mathrm{s}, \mathrm{SiMe}), 4.59\left(2 \mathrm{H}, \mathrm{s}, \mathrm{SiCH}_{2} \mathrm{~N}\right), 7.68(1 \mathrm{H}$, s, H-3), 8.51 (1H, dd, $J 10.1$ and 9.8, H-7), 8.60 (1H, dd, $J 10.2$ and 9.9, H-5), 8.71 (1H, dd, $J 10.2$ and 9.8, H-6), 9.06 (1H, d, J 9.9, H-4), and 9.47 (1H, d, $J$ 10.1, H-8); $\delta_{\mathrm{C}}-1.8,39.2,112.0,135.3,137.5,137.9$, 142.1, 143.3, 143.8, 144.9, and 146.3. Anal. Calcd for $\mathrm{C}_{14} \mathrm{H}_{17} \mathrm{NO}_{3} \mathrm{ClF}_{3} \mathrm{SSi}: \mathrm{C}, 42.05 \mathrm{H}, 4.28 ; \mathrm{N}, 3.50$. Found: C, 42.33; H, 4.37; N, 3.44.

In the similar manner, compounds $\mathbf{4 b}(90 \%), \mathbf{4 c}(92 \%), \mathbf{4 d}(96 \%), \mathbf{4 e}(64 \%)$, and $\mathbf{4 f}(79 \%)$ were obtained. 4b: Yellow oil; $\delta_{\mathrm{H}} 0.32(9 \mathrm{H}, \mathrm{s}, \mathrm{SiMe}), 4.42\left(2 \mathrm{H}, \mathrm{s}, \mathrm{SiCH}_{2} \mathrm{~N}\right), 4.65,(3 \mathrm{H}, \mathrm{s}, \mathrm{OMe}), 7.51(1 \mathrm{H}, \mathrm{s}, \mathrm{H}-3), 8.37$ (1H, dd, $J 10.1$ and 9.7, H-7), 8.47 (1H, dd, $J 10.1$ and 9.9, H-5), 8.56 (1H, dd, $J 10.1$ and 9.7, H-6), 9.05 $\left(1 \mathrm{H}, \mathrm{d}, J\right.$ 9.9, H-4), and $9.09(1 \mathrm{H}, \mathrm{d}, J 10.1, \mathrm{H}-8) ; \delta_{\mathrm{C}}-2.1,35.9,60.9,93.1,129.4,135.6,136.4,138.9$, 141.2, 142.5, 145.6, and 165.6. Anal. Calcd for $\mathrm{C}_{15} \mathrm{H}_{20} \mathrm{NO}_{4} \mathrm{~F}_{3} \mathrm{SSi}$. C, $42.56 \mathrm{H}, 5.10 ; \mathrm{N}, 3.54$. Found: C, 42.46; H, 5.02; N, 3.45.

4c: Orange prisms $\left(\mathrm{Et}_{2} \mathrm{O}-\mathrm{CH}_{2} \mathrm{Cl}_{2}\right), \mathrm{mp} 132-133{ }^{\circ} \mathrm{C} ; \delta_{\mathrm{H}} 0.00(9 \mathrm{H}, \mathrm{s}, \mathrm{SiMe}), 1.76-1.88(6 \mathrm{H}, \mathrm{m}, \mathrm{H}-3$ ', 4', and 5'), 3.52 (4H, t, J 5.7, H-2' and 6'), $4.27\left(2 \mathrm{H}, \mathrm{s}, \mathrm{SiCH}_{2} \mathrm{~N}\right), 6.99(1 \mathrm{H}, \mathrm{s}, \mathrm{H}-3), 7.87-7.98$ (2H, m, H-5 and 7), 8.10 (like t, $J$ 9.9, H-6), $8.46(1 \mathrm{H}, \mathrm{d}, J 9.9, \mathrm{H}-4)$, and $8.66(1 \mathrm{H}, \mathrm{d}, J 9.9, \mathrm{H}-8) ; \delta_{\mathrm{C}}-1.5,23.5,25.3$, $38.8,52.5,116.1,119.3,122.5,128.1,134.7,135.8,136.3,139.4,145.8,146.0$, and 162.2. Anal. 
Calcd for $\mathrm{C}_{19} \mathrm{H}_{27} \mathrm{NO}_{3} \mathrm{~F}_{3} \mathrm{SSi}$ C, $50.87 \mathrm{H}, 6.07 ; \mathrm{N}, 6.24$. Found: C, 50.90; H, 5.87; N, 6.35.

4d: Orange prisms $\left(\mathrm{Et}_{2} \mathrm{O}-\mathrm{CH}_{2} \mathrm{Cl}_{2}\right), \mathrm{mp} 186-187{ }^{\circ} \mathrm{C} ; \delta_{\mathrm{H}} 0.13(9 \mathrm{H}, \mathrm{s}, \mathrm{SiMe}), 1.41(3 \mathrm{H}, \mathrm{t}, J 7.2, \mathrm{Me}), 3.63$ $\left(2 \mathrm{H}, \mathrm{qd}, J\right.$ 7.2 and 6.8, $\left.\mathrm{MeCH}_{2} \mathrm{NH}\right), 4.11\left(2 \mathrm{H}, \mathrm{s}, \mathrm{SiCH}_{2} \mathrm{~N}\right), 6.50(1 \mathrm{H}, \mathrm{s}, \mathrm{H}-3), 7.48-7.66(4 \mathrm{H}, \mathrm{m}, \mathrm{H}-4,5,6$, and 7), $7.96(1 \mathrm{H}, \mathrm{d}, J 10.2, \mathrm{H}-8)$, and $8.67\left(1 \mathrm{H}\right.$, br t, $J$ 6.8); $\delta_{\mathrm{C}}-1.9,14.3,35.1,40.2,95.9,120.4,131.7$, 132.3, 134.5, 134.7, 145.9 and 158.1. Anal. Calcd for $\mathrm{C}_{16} \mathrm{H}_{23} \mathrm{~N}_{2} \mathrm{O}_{3} \mathrm{~F}_{3} \mathrm{SSi}$ : C, $47.04 \mathrm{H}, 5.67$; N, 6.86. Found: C, 47.40; H, 5.61; N, 6.73.

4e: Orange prisms $\left(\mathrm{Et}_{2} \mathrm{O}-\mathrm{CH}_{2} \mathrm{Cl}_{2}\right), \mathrm{mp} 221-222{ }^{\circ} \mathrm{C} ; \delta_{\mathrm{H}} 0.13(9 \mathrm{H}, \mathrm{s}, \mathrm{SiMe}), 4.02\left(2 \mathrm{H}, \mathrm{s}, \mathrm{SiCH}_{2} \mathrm{~N}\right), 6.85$ (1H, s, H-3), 7.46-7.56 (4H, m,H-4, 5, 6, and 7), 7.92-9.94 (1H, m, H-8), and 7.95 (2H, br s, NH). Anal. Calcd for $\mathrm{C}_{14} \mathrm{H}_{19} \mathrm{~N}_{2} \mathrm{O}_{3} \mathrm{~F}_{3}$ SSi: C, 44.20 H, 5.03; N, 7.36. Found: C, 44.35; H, 5.21; N, 7.16.

\section{Generation and reaction of 1-azaazulene $N$-methylides with dimethyl acetylenedicarboxylate (DMAD)}

Typical procedure A - Under argon atmosphere, a mixture of CsF (0.281 g, 1.85 mmol), DMAD (0.171 g, $1.20 \mathrm{mmol}), 4 \mathbf{a}(0.370 \mathrm{~g}, 0.92 \mathrm{mmol})$, and $N, N$-dimethylacetamide (DMA) (10 mL) in a sealed tube was stirred for $6 \mathrm{~h}$. To the mixture was added water, then the mixture was extracted with $\mathrm{CH}_{2} \mathrm{Cl}_{2}$. The extract was dried over $\mathrm{Na}_{2} \mathrm{SO}_{4}$, and the solvent was evaporated. Chromatography of the residue with hexane-AcOEt (2 : 1) gave 5aa (0.029 g, 10\%), 6aa (0.052 g, 18\%), 7 (0.006 g, 2\%), and 8 (0.0016 g, $0.4 \%)$, successively.

Typical procedure B - Under argon atmosphere, a mixture of CsF (0.082 g, 0.54 mmol), DMAD (0.08 $\mathrm{mL}, 0.65 \mathrm{mmol}), 4 \mathbf{a}(0.149 \mathrm{~g}, 0.37 \mathrm{mmol})$, and $\mathrm{MeCN}(3 \mathrm{~mL})$ in a sealed tube was stirred for $22 \mathrm{~h}$. Then, $p$-chloranil $(0.103 \mathrm{~g}, 0.042 \mathrm{mmol})$ was added to the mixture, and stirring was continued for $24 \mathrm{~h}$. To the mixture was added water, then the mixture was extracted with AcOEt. The extract was dried over $\mathrm{Na}_{2} \mathrm{SO}_{4}$, and the solvent was evaporated. Chromatography of the residue with hexane-AcOEt (3 : 1) gave 5aa $(0.010 \mathrm{~g}, 9 \%)$ and 6aa $(0.020 \mathrm{~g}, 17 \%)$, successively.

5aa: Dark violet prisms (hexane- $\left.\mathrm{CH}_{2} \mathrm{Cl}_{2}\right), \mathrm{mp} 138-140{ }^{\circ} \mathrm{C} ; \delta_{\mathrm{H}} 3.73,(3 \mathrm{H}, \mathrm{s}, \mathrm{Me}), 3.77(3 \mathrm{H}, \mathrm{s}, \mathrm{Me}), 4.95$ (1H, dd, $J 11.2$ and 7.8, H-8), 5.28 (1H, ddd, $J$ 12.8, 7.8, and 0.7, H-7), 5.59 (1H, d, $J$ 12.8, H-9), 5.72 $(1 \mathrm{H}, \mathrm{dd}, J 11.2$ and $0.7, \mathrm{H}-6), 6.07(1 \mathrm{H}, \mathrm{s}, \mathrm{H}-1)$, and $7.36(1 \mathrm{H}, \mathrm{s}, \mathrm{H}-3) ; \delta_{\mathrm{C}} 52.2,52.3,111.2,111.3,112.2$, $119.1,121.5,123.7,124.3,128.5,133.2,134.0,137.3,139.1,164.8$, and 167.6; $v(\mathrm{C}=\mathrm{O}) / \mathrm{cm}^{-1} 1725$ and 1714; $\lambda_{\max }(\mathrm{MeCN}) \mathrm{nm}(\log \varepsilon) 233$ (4.62), 356 (4.01), and 550 (2.48); $\mathrm{m} / z$ (rel intensity) $319\left(\mathrm{M}^{+}, 38\right)$, $317\left(\mathrm{M}^{+}, 100\right), 286$ (39), 271 (30), 200 (33), and 164 (20). Anal. Calcd for $\mathrm{C}_{16} \mathrm{H}_{12} \mathrm{NO}_{4} \mathrm{Cl}: \mathrm{C}, 60.48 ; \mathrm{H}$, 3.82; N, 4.41. Found: C, 60.36; H, 4.03; N, 4.44.

6aa: Yellow prisms (hexane- $\left.\mathrm{CH}_{2} \mathrm{Cl}_{2}\right), \mathrm{mp} 183-184{ }^{\circ} \mathrm{C} ; \delta_{\mathrm{H}} 3.91,(3 \mathrm{H}, \mathrm{s}, \mathrm{Me}), 4.06(3 \mathrm{H}, \mathrm{s}, \mathrm{Me}), 7.06(1 \mathrm{H}$, s, H-5), 7.14-7.56 (3H, m, H-6, 7, and 8), $8.12(1 \mathrm{H}, \mathrm{s}, \mathrm{H}-3)$, and $8.19\left(1 \mathrm{H}, \mathrm{d}, J\right.$ 8.0, H-9); $\delta_{\mathrm{C}} 52.0,53.0$, $111.4,113.4,117.4,117.5,123.3,123.8,124.4,126.8,127.8,128.0,128.5,129.5,163.8$, and 167.5; 
$v(\mathrm{C}=\mathrm{O}) / \mathrm{cm}^{-1} 1723$ and 1710; $\lambda_{\max }(\mathrm{MeCN}) \mathrm{nm}(\log \varepsilon) 264$ (4.78), 307 (3.87), and $320(3.84) ; \mathrm{m} / z$ (rel intensity) $317\left(\mathrm{M}^{+}, 28\right), 317\left(\mathrm{M}^{+}, 75\right), 286$ (100), 256 (21), 227 (10), 214 (10), and 164 (34). Anal. Calcd for $\mathrm{C}_{16} \mathrm{H}_{12} \mathrm{NO}_{4} \mathrm{Cl}$ : C, 60.48; H, 3.82; N, 4.41. Found: C, 60.22; H, 3.98; N, 4.57.

7: Green needles (hexane- $\left.\mathrm{CH}_{2} \mathrm{Cl}_{2}\right), \mathrm{mp} 165-166{ }^{\circ} \mathrm{C} ; \delta_{\mathrm{H}} 3.91,(3 \mathrm{H}, \mathrm{s}, \mathrm{Me}), 3.92(3 \mathrm{H}, \mathrm{s}, \mathrm{Me}), 6.73(1 \mathrm{H}$, dd, $J 11.2$ and 8.3, H-7), $6.82(1 \mathrm{H}, \mathrm{dd}, J 11.2$ and 8.5, H-8), $6.92(1 \mathrm{H}, \mathrm{dd}, J 11.3$ and 8.3, H-6), 6.98 (1H, s, $\mathrm{H}-4), 7.40\left(1 \mathrm{H}, \mathrm{d}, J\right.$ 8.5, H-9), $7.51(1 \mathrm{H}, \mathrm{d}, J 11.3, \mathrm{H}-5)$, and $8.04(1 \mathrm{H}, \mathrm{s}, \mathrm{H}-1) ; \delta_{\mathrm{C}} 51.3,52.0,107.6,115.6$, $115.8,122.1,126.7,127.0,133.1,133.4,139.3,139.9,146.1,151.8,164.0$, and $164.5 ; v(\mathrm{C}=\mathrm{O}) / \mathrm{cm}^{-1}$ 1701 and 1673; m/z (rel intensity) $283\left(\mathrm{M}^{+}, 100\right), 252$ (90), 225 (18), 222 (11), 194 (18), 180 (13), 167 (34), 166 (25), and 139 (16). Anal. Calcd for $\mathrm{C}_{16} \mathrm{H}_{13} \mathrm{NO}_{4}: \mathrm{C}, 67.84 ; \mathrm{H}, 4.63 ; \mathrm{N}, 4.94$. Found: C, 67.56; H, 4.57; N, 4.98.

8: Reddish violet needles (hexane- $\left.\mathrm{CH}_{2} \mathrm{Cl}_{2}\right), \mathrm{mp} 209-210{ }^{\circ} \mathrm{C} ; \delta_{\mathrm{H}} 4.03,(3 \mathrm{H}, \mathrm{s}, \mathrm{Me}), 4.04(3 \mathrm{H}, \mathrm{s}, \mathrm{Me}), 4.07$ $(3 \mathrm{H}, \mathrm{s}, \mathrm{Me}), 4.08$ (3H, s, Me), $6.56(1 \mathrm{H}, \mathrm{dd}, J 11.1$ and 8.7, H-8), 6.85 (1H, dd, $J 12.1$ and 8.7, H-7), 7.22 $(1 \mathrm{H}, \mathrm{d}, J$ 12.1, H-6), 7.57 (1H, dd, $J 11.1, \mathrm{H}-9)$, and $7.73(1 \mathrm{H}, \mathrm{s}, \mathrm{H}-3) ; v(\mathrm{C}=\mathrm{O}) / \mathrm{cm}^{-1} 1725,1705$, and 1697; $\mathrm{m} / \mathrm{z}$ (rel intensity) $423\left(\mathrm{M}^{+}, 100\right), 392$ (34), 377 (13), 217 (24), 190 (12), 189 (22), and 188 (17). Anal. Calcd for $\mathrm{C}_{22} \mathrm{H}_{17} \mathrm{NO}_{8}:$ C, 62.41; H, 4.05; N, 3.31. Found: C, 62.53; H, 4.12; N, 3.13.

5ba: Dark violet prisms (hexane- $\left.\mathrm{CH}_{2} \mathrm{Cl}_{2}\right), \mathrm{mp} 124-127{ }^{\circ} \mathrm{C} ; \delta_{\mathrm{H}} 3.68,(3 \mathrm{H}, \mathrm{s}, \mathrm{Me}), 3.72(3 \mathrm{H}, \mathrm{s}, \mathrm{Me}), 3.82$ $(3 \mathrm{H}, \mathrm{s}, \mathrm{Me}), 4.91(1 \mathrm{H}, \mathrm{dd}, J 11.2$ and 7.9, H-8), $5.26(1 \mathrm{H}, \mathrm{dd}, J 12.8$ and 7.9, H-7), 5.35 (1H, s, H-1), 5.71 $\left(1 \mathrm{H}, \mathrm{d}, J\right.$ 12.8, H-9), $5.72\left(1 \mathrm{H}, \mathrm{dd}, J\right.$ 11.2, H-6), and $7.02(1 \mathrm{H}, \mathrm{s}, \mathrm{H}-3) ; v(\mathrm{C}=\mathrm{O}) / \mathrm{cm}^{-1} 1727$ and 1703. Anal. Calcd for $\mathrm{C}_{17} \mathrm{H}_{15} \mathrm{NO}_{5}: \mathrm{C}, 65.17 ; \mathrm{H}, 4.83 ; \mathrm{N}, 4.47$. Found: C, 65.04; H, 4.88; N, 4.63.

6ba: Yellow prisms (hexane- $\left.\mathrm{CH}_{2} \mathrm{Cl}_{2}\right), \mathrm{mp} 146-147{ }^{\circ} \mathrm{C} ; \delta_{\mathrm{H}} 3.89,(3 \mathrm{H}, \mathrm{s}, \mathrm{Me}), 4.04(3 \mathrm{H}, \mathrm{s}, \mathrm{Me}), 4.12(3 \mathrm{H}$, s, Me), $6.14(1 \mathrm{H}, \mathrm{s}, \mathrm{H}-5), 7.43-7.53(2 \mathrm{H}, \mathrm{m}, \mathrm{H}-7$ and 8), $7.52(1 \mathrm{H}, \mathrm{dd}, J 7.9$ and 1.2, H-6), $8.00(1 \mathrm{H}, \mathrm{s}$, $\mathrm{H}-3)$, and $8.19(1 \mathrm{H}, \mathrm{d}, J 7.4, \mathrm{H}-9) ; v(\mathrm{C}=\mathrm{O}) / \mathrm{cm}^{-1} 1725$ and $1711 ; \mathrm{m} / z$ (rel intensity) $313\left(\mathrm{M}^{+}, 100\right), 298$ (69), 282 (91), 267 (56), 181 (19), and 126 (13). Anal. Calcd for $\mathrm{C}_{17} \mathrm{H}_{15} \mathrm{NO}_{5}$ : C, 65.17; H, 4.83; N, 4.47. Found: C, 65.28; H, 4.78; N, 4.50.

6ca: Yellow oil; $\delta_{\mathrm{H}} 1.13-1.18\left(6 \mathrm{H}, \mathrm{m}, \mathrm{H}-3^{\prime}, 4^{\prime}\right.$, and 5'), 1.75-1.77 (4H, m, H-2' and 6'), 3.83, (3H, s, Me), 3.97 (3H, s, Me), 6.34 (1H, s, H-5), 7.30-7.50 (3H, m, H-6, 7, and 8), $7.86(1 \mathrm{H}, \mathrm{s}, \mathrm{H}-3)$, and $8.10(1 \mathrm{H}, \mathrm{d}$, $J$ 9.4, $\mathrm{H}-9) ; v(\mathrm{C}=\mathrm{O}) / \mathrm{cm}^{-1}$ (Neat) 1730 and 1728; $\mathrm{m} / \mathrm{z}$ (rel intensity) $366\left(\mathrm{M}^{+}, 100\right), 335(16), 303(15)$, 285 (13), 149 (27), and 87 (23).

9: Red oil; $\delta_{\mathrm{H}} 1.50-1.57$ (6H, m, H-3', 4', and 5'), 2,97-3.02 (2H, m, H-2' and 6'), 3.20-2.25 (2H, m, H-2' and 6'), 3.55 (3H, s, Me), 3.64, (3H, s, Me), 3.67 (3H, s, Me), $3.76(3 \mathrm{H}, \mathrm{s}, \mathrm{Me}), 4.18(1 \mathrm{H}, \mathrm{d}, J$ 15.4, H-3), $4.25(1 \mathrm{H}, \mathrm{d}, J 15.4, \mathrm{H}-3), 5.32(1 \mathrm{H}, \mathrm{d}, J 10.3, \mathrm{H}-9), 5.69$ (1H, s, vinylic-H), $5.83(1 \mathrm{H}, \mathrm{dd}, J 11.0$ and 6.7 , H-7), 5.94 (1H, d, J 7.4, H-5a), 6.08 (1H, dd, J 10.3 and 6.7, H-8), and 6.28 (1H, dd, J 11.0 and 7.4, H-6). $v(\mathrm{C}=\mathrm{O}) / \mathrm{cm}^{-1}$ (Neat) 17201713,1698 , and 1680; $\mathrm{m} / \mathrm{z}$ (rel intensity) $510\left(\mathrm{M}^{+}, 100\right)$. 


\section{Reaction of 7 with DMAD}

A mixture of 7 (0.045 g, $0.16 \mathrm{mmol})$ and DMAD (0.046 g, $0.32 \mathrm{mmol})$ in MeCN (5 mL) was stirred for $21 \mathrm{~h}$ at rt, and evaporated. Chromatography of the residue with hexane-AcOEt (2:1) gave 8 (8 mg, $12 \%)$ and $7(0.030 \mathrm{~g}, 67 \%)$.

\section{Generation and reaction of 1-azaazulene $N$-ylides with methylplopiolate (MP)}

Procedure A - Under argon atmosphere, a mixture of CsF (0.211 g, $1.39 \mathrm{mmol})$, MP (0.135 g, 0.78 $\mathrm{mmol}), 4 \mathbf{a}(0.278 \mathrm{~g}, 0.69 \mathrm{mmol}), \mathrm{Yb}\left(\mathrm{CF}_{3} \mathrm{SO}_{3}\right)_{3}(0.043 \mathrm{~g}, 0.07 \mathrm{mmol})$, and DMA $(10 \mathrm{~mL})$ in a sealed tube was stirred for $60 \mathrm{~h}$. To the mixture was added water, then the mixture was extracted with $\mathrm{CH}_{2} \mathrm{Cl}_{2}$. The extract was dried over sodium sulfate, and the solvent was evaporated. Chromatography of the residue with hexane-ethyl acetate $(10: 1)$ gave $5 \mathbf{a b}(0.0026 \mathrm{~g}, 2 \%)$ and $\mathbf{6 a b}(0.0074 \mathrm{~g}, 4 \%)$.

Procedure B - Under argon atmosphere, a mixture of CsF (0.172 g, $1.12 \mathrm{mmol}), \mathrm{MP}(0.11 \mathrm{~mL}, 1.20$ $\mathrm{mmol})$, 4a $(0.306 \mathrm{~g}, 0.77 \mathrm{mmol})$, and $\mathrm{MeCN}(6 \mathrm{~mL})$ in a sealed tube was stirred for $21 \mathrm{~h}$. Then, p-chloranil $(0.211 \mathrm{~g}, 0.86 \mathrm{mmol})$ was added to the mixture, and stirring was continued for $24 \mathrm{~h}$. To the mixture was added water, then the mixture was extracted with AcOEt. The extract was dried over $\mathrm{Na}_{2} \mathrm{SO}_{4}$, and the solvent was evaporated. Chromatography of the residue with benzene gave $6 \mathbf{a b}(0.006$ $\mathrm{g}, 3 \%)$.

5ab; Dark violet prisms (hexane- $\left.\mathrm{CH}_{2} \mathrm{Cl}_{2}\right), \mathrm{mp} 118-120{ }^{\circ} \mathrm{C} ; \delta_{\mathrm{H}} 3.72,(3 \mathrm{H}, \mathrm{s}, \mathrm{Me}), 5.19(1 \mathrm{H}, \mathrm{dd}, J 10.9$ and 7.9, H-8), 5.61 (1H, dd, $J 13.0$ and 7.9, H-7), 6.01 (1H, d, J 10.9, H-9), 6.09 (1H, s, H-1), 6.42 (1H, d, $J$ 7.6, H-4), 6.67 (1H, d, J 7.6, H-3), $7.16(1 \mathrm{H}, \mathrm{d}, J 13.0, \mathrm{H}-6) ; v(\mathrm{C}=\mathrm{O}) / \mathrm{cm}^{-1}$ (Nujol) 1714; $\mathrm{m} / z$ (rel intensity) $261\left(\mathrm{M}^{+}, 38\right), 259\left(\mathrm{M}^{+}, 100\right)$. Anal. Calcd for $\mathrm{C}_{14} \mathrm{H}_{10} \mathrm{NO}_{2} \mathrm{Cl}: \mathrm{C}, 64.75 ; \mathrm{H}, 3.88 ; \mathrm{N}, 5.39$. Found: C, 64.52; H, 3.65; N, 5.57.

6ab: Yellow oil; $\delta_{\mathrm{H}} 3.95,(3 \mathrm{H}, \mathrm{s}, \mathrm{Me}), 7.13(1 \mathrm{H}, \mathrm{s}, \mathrm{H}-5), 7.34(1 \mathrm{H}, \mathrm{d}, J 3.3, \mathrm{H}-2), 7.50-7.63$ (3H, m, H-6, 7, and 8), $7.65(1 \mathrm{H}, \mathrm{d}, J 3.3, \mathrm{H}-3)$, and $9.82(1 \mathrm{H}, \mathrm{d}, J 7.9, \mathrm{H}-9) ; v(\mathrm{C}=\mathrm{O}) / \mathrm{cm}^{-1}$ (Neat) $1715 ; \mathrm{m} / z$ (rel intensity) $261\left(\mathrm{M}^{+}, 33\right), 259\left(\mathrm{M}^{+}, 82\right), 228(100), 201(22)$, and $172(22)$.

\section{Generation and reaction of 1-azaazulene $N$-ylides with electron-deficient olefins}

Typical procedure A - Under argon atmosphere, a mixture of CsF (0.525 g, $3.46 \mathrm{mmol})$, $N$-phenylmaleimide $(0.390 \mathrm{~g}, 2.25 \mathrm{mmol}), 4 \mathbf{a}(0.692 \mathrm{~g}, 1.73 \mathrm{mmol})$, and DMA $(20 \mathrm{~mL})$ in a sealed tube was stirred for $1 \mathrm{~h}$. To the mixture was added water, then the mixture was extracted with $\mathrm{CH}_{2} \mathrm{Cl}_{2}$. The extract was dried over $\mathrm{Na}_{2} \mathrm{SO}_{4}$, and the solvent was evaporated. Chromatography of the residue with benzene gave 12aa $(0.186 \mathrm{~g}, 31 \%)$.

Typical procedure B - Under argon atmosphere, a mixture of cesium fluoride (0.144 g, $0.95 \mathrm{mmol})$, 
$N$-methylmaleimide $(0.113 \mathrm{~g}, 1.02 \mathrm{mmol}), 4 \mathbf{a}(0.260 \mathrm{~g}, 0.65 \mathrm{mmol})$, and $\mathrm{MeCN}(6 \mathrm{~mL})$ in a sealed tube was stirred for $21 \mathrm{~h}$. Then, $p$-chloranil $(0.179 \mathrm{~g}, 0.73 \mathrm{mmol})$ was added to the mixture, and stirring was continued for $24 \mathrm{~h}$. To the mixture was added water, then the mixture was extracted with AcOEt. The extract was dried over sodium sulfate, and the solvent was evaporated. Chromatography of the residue with benzene gave 12ab $(0.010 \mathrm{~g}, 5 \%)$.

12a; Green prisms (hexane- $\left.\mathrm{CH}_{2} \mathrm{Cl}_{2}\right), \mathrm{mp} 209-211{ }^{\circ} \mathrm{C}$; $\delta_{\mathrm{H}} 5.48(1 \mathrm{H}, \mathrm{dd}, J 11.2$ and 8.0, $\mathrm{H}-3), 5.90(1 \mathrm{H}$, dd, $J 12.4$ and 8.0, H-2), $6.19(1 \mathrm{H}, \mathrm{d}, J 11.2, \mathrm{H}-4), 6.31(1 \mathrm{H}, \mathrm{s}, \mathrm{H}-5), 7.18(1 \mathrm{H}, \mathrm{d}, J 12.4, \mathrm{H}-1), 7.35-7.38(3 \mathrm{H}$, m, H-m,p-pheny), 7.45-7.49 (2H, m, H-o-phenyl), and $7.43(1 \mathrm{H}, \mathrm{s}, \mathrm{H}-7) ; v(\mathrm{C}=\mathrm{O}) / \mathrm{cm}^{-1}$ (Nujol) 1744 and 1668; $m / z$ (rel intensity) $348\left(\mathrm{M}^{+}, 38\right), 346\left(\mathrm{M}^{+}, 100\right), 302$ (6), 301 (8), 267 (19), 266 (10), 237 (8), 199 (20), and 164 (25). Anal. Calcd for $\mathrm{C}_{20} \mathrm{H}_{11} \mathrm{~N}_{2} \mathrm{O}_{2} \mathrm{Cl}: \mathrm{C}, 69.27 ; \mathrm{H}, 3.20 ; \mathrm{N}, 8.08$. Found: C, 69.37; H, $3.37 ; \mathrm{N}, 7.99$.

12ab: Green needles (hexane- $\left.\mathrm{CH}_{2} \mathrm{Cl}_{2}\right), \operatorname{mp} 223-225{ }^{\circ} \mathrm{C} ; \delta_{\mathrm{H}} 3.05,(3 \mathrm{H}, \mathrm{s}, \mathrm{Me}), 5.42(1 \mathrm{H}, \mathrm{dd}, J 11.2$ and 8.0, H-2), 5.84 (1H, dd, $J 12.4$ and 8.0, H-2), 6.13 (1H, d, J 11.2, H-4), 6.24 (1H, s, H-5), 7.07 (1H, d, $J$ 12.4, $\mathrm{H}-1)$, and $7.43(1 \mathrm{H}, \mathrm{s}, \mathrm{H}-7) ; v(\mathrm{C}=\mathrm{O}) / \mathrm{cm}^{-1} 1741$ and 1698; $\mathrm{m} / \mathrm{z}$ (rel intensity) $286\left(\mathrm{M}^{+}, 38\right), 284\left(\mathrm{M}^{+}, 100\right)$, 249 (1), 239 (13), 199 (28), and 164 (16). Anal. Calcd for $\mathrm{C}_{15} \mathrm{H}_{9} \mathrm{~N}_{2} \mathrm{O}_{2} \mathrm{Cl}$ : C, 63.28; H, 3.19; N, 9.84. Found: C, 63.45; H, 3.38; N, 9.66.

12ca; Green fibers (hexane- $\mathrm{CH}_{2} \mathrm{Cl}_{2}$ ), mp 277-279 ${ }^{\circ} \mathrm{C}$; $\delta_{\mathrm{H}} 1.58-1.63(2 \mathrm{H}, \mathrm{m}, \mathrm{H}-4$ '), 1.69-1.74 (4H, H-3' and 5'), 2.82-2.80 (4H, m, H-2' and 6'), $5.43(1 \mathrm{H}, \mathrm{dd}, J 11.0$ and 8.0, H-3), $5.88(1 \mathrm{H}, \mathrm{dd}, J 12.3$ and 8.0, H-2), 5.87 (1H, s, H-5), 6.23 (1H, d, J 11.1, H-4), 7.15 (1H, d, J 12.3, H-1), 7.43 (1H, s, H-7), 7.32-7.38 (3H, m, H-m,p-pheny), and 7.44-7.48 (2H, m, H-o-phenyl); $\delta_{\mathrm{C}} 24.4,26.1,52.4,101.3,102.6,118.2$, $120.7,125.5,126.7,127.1,128.1,128.2,129.2,132.8,135.5,137.3,138.3,141.4,142.8,165.1$, and

165.5; $v(\mathrm{C}=\mathrm{O}) / \mathrm{cm}^{-1}$ (Nujol) 1730 and 1693. Anal. Calcd for $\mathrm{C}_{25} \mathrm{H}_{21} \mathrm{~N}_{3} \mathrm{O}_{2}: \mathrm{C}, 75.93 ; \mathrm{H}, 5.35 ; \mathrm{N}, 10.63$. Found: C, 75.77; H, 5.25; N, 10.56.

13cb; Orange oil; $\delta_{\mathrm{H}}$ 1.70-1.83 (6H, m, H-3', 4', and 5'), 2.86-2.99 (4H, m, H-2' and 6'), 3.07 (3H, s, Me), $3.33(1 \mathrm{H}, \mathrm{dd}, 12.3$ and 10.8, H-7), 3.57 (1H, dd, $J 12.3$ and 6.3, H-7), $4.79(1 \mathrm{H}, \mathrm{dd}, J 10.8$ and 6.3, H-7a), $5.95(1 \mathrm{H}, \mathrm{s}, \mathrm{H}-5), 6.41(1 \mathrm{H}, \mathrm{dd}, J 10.8$ and 8.3, H-3), $6.72(1 \mathrm{H}, \mathrm{dd}, J 12.1$ and 8.3, H-2), $7.02(1 \mathrm{H}$, $\mathrm{d}, J 10.8, \mathrm{H}-4)$, and 8.28 (1H, d, $J 12.1, \mathrm{H}-1) ; m / z$ (rel intensity) $335\left(\mathrm{M}^{+}, 100\right)$.

\section{Synthesis of 1-trimethylsilylmethyl-1,3-diazaazulenium triflate}

Under argon atmosphere, a mixture of 1,3-diazaazulene (14) $(0.127 \mathrm{~g}, 0.98 \mathrm{mmol})$, trimethylsilylmethyl triflate $(0.277 \mathrm{mg} 1.17 \mathrm{mmol})$ in dry $\mathrm{CH}_{2} \mathrm{Cl}_{2}(60 \mathrm{~mL})$ was stirred for $48 \mathrm{~h}$ at $\mathrm{rt}$. To the mixture $\mathrm{Et}_{2} \mathrm{O}$ $(300 \mathrm{~mL})$ was added, and stirring was continued for $5 \mathrm{~h}$. The precipitate was collected by filtration and 1-trimethylsilylmethyl-1,3-diazaazulenium triflate (15) (0.268 g, 79\%) was obtained.

15: Colorless plates (hexane-dichloromethane), mp 137-138 ${ }^{\circ} \mathrm{C} ; \delta_{\mathrm{H}} 0.16(9 \mathrm{H}, \mathrm{s}, \mathrm{SiMe}), 4.59(2 \mathrm{H}, \mathrm{s}$, 
$\left.\mathrm{SiCH}_{2} \mathrm{~N}\right), 8.79(1 \mathrm{H}, \mathrm{dd}, J 10.0$ and 9.8, H-7), 8.92 (1H, t, $J$ 9.9, H-5), 9.01 (1H, dd, $J 9.9$ and 9.8, H-6), $9.09(1 \mathrm{H}, \mathrm{s}, \mathrm{H}-2), 9.34\left(1 \mathrm{H}, \mathrm{d}, J\right.$ 9.9, H-4), $9.74(1 \mathrm{H}, \mathrm{d}, J 10.0, \mathrm{H}-8) ; \delta_{\mathrm{C}}-2.4,39.6,135.8,140.7,141.6$, 144.1, 148.2, 149.3, 156.2, and 158.8. Anal. Calcd for $\mathrm{C}_{14} \mathrm{H}_{17} \mathrm{NO}_{3} \mathrm{ClF}_{3} \mathrm{SSi}: \mathrm{C}, 42.61 \mathrm{H}, 4.68 ; \mathrm{N}, 7.64$. Found: C, 42.46; H, 4.57; N, 7.48.

\section{Generation and reaction of 1,3-diazaazulene 1-methylide (14) with DMAD}

Under argon atmosphere, a mixture of CsF (0.168 g, $1.11 \mathrm{mmol})$, DMAD (0.118 g, 0.83 mmol), 15 $(0.203 \mathrm{~g}, 0.55 \mathrm{mmol})$, and $\mathrm{MeCN}(10 \mathrm{~mL})$ in a sealed tube was stirred for $5 \mathrm{~h}$ under cooling on ice-bath, then the stirring was continued for $24 \mathrm{~h}$ at $\mathrm{rt}$. To the mixture was added water, then the mixture was extracted with $\mathrm{CH}_{2} \mathrm{Cl}_{2}$. The extract was dried over $\mathrm{Na}_{2} \mathrm{SO}_{4}$, and the solvent was evaporated. Chromatography of the residue with hexane-AcOEt(2 : 1) gave $16(0.014 \mathrm{~g}, 9 \%)$.

16: Colorless plates (hexane- $\left.\mathrm{CH}_{2} \mathrm{Cl}_{2}\right), \mathrm{mp} 146-148{ }^{\circ} \mathrm{C} ; \delta_{\mathrm{H}} 3.91,(3 \mathrm{H}, \mathrm{s}, \mathrm{Me}), 4.03(3 \mathrm{H}, \mathrm{s}, \mathrm{Me}), 7.56(1 \mathrm{H}$, ddd, $J$ 8.3, 7.8 and 1.7, H-8), 7.58 (1H, ddd, $J$ 8.3, 7.8, and 1.6, H-7), $7.81(1 \mathrm{H}, \mathrm{s}, \mathrm{H}-3), 7.84(1 \mathrm{H}, \mathrm{dd}, J$ 7.8 and 1.6, H-9), 8.37 (1H, dd, $J 7.8$ and 1.7, H-6), and $8.64(1 \mathrm{H}, \mathrm{s}, \mathrm{H}-4) ; m / z$ (rel intensity) $284\left(\mathrm{M}^{+}\right.$, 41), 253 (100), 221 (18), 194 (5), and 168 (6). Anal. Calcd for $\mathrm{C}_{13} \mathrm{H}_{12} \mathrm{~N}_{2} \mathrm{O}_{4}: \mathrm{C}, 63.38 ; \mathrm{H}, 4.25 ; \mathrm{N}, 9.85$. Found: C, 63.20; H, 3.92; N, 9.97.

\section{ACKNOWRIDGEMENTS}

This work was partially supported by a Grand-in Aid for Scientific Research on Priority Areas (A) of Exploitation of Multi-Element Cyclic Molecules (Nos. 13029083 and 14044074) from the Ministry of Education, Culture, Sports, Science and Technology, Japan.

\section{REFERENCES}

1. A. W. Johnson, 'Ylid Chemistry,'Academic Press, New York, 1966, chapter 7.

2. I. Zugravescu and M. Petrovanu, 'N-Ylid Chemistry,' McGraw-Hill, New York, 1976.

3. O. Tsuge and S. Kanemasa, Adv. Heterocycl. Chem., 1989, 45, 231.

4. T. Okamoto and M. Hirobe, Yuki Gosei Kagaku Kyoukaishi, 1968, 26, 746.

5. H.-J. Timp, Adv. Heterocycl. Chem., 1974, 17, 213.

6. W. J. McKillop, E. A. Sedor, B. M. Culbertson, and S. Wawzonek, Chem. Rev., 1973, 73, 255.

7. Y. Tamura, J. Minamikawa, and M. Ikeda, Synthesis, 1977, 1.

8. Y. Tamura and M. Ikeda, Adv. Heterocycl. Chem., 1981, 29, 71.

9. A. Padwa, '1,3-Dipolar Cycloaddition Chemistry, Vols. 1 and 2,' Wiley, New York, 1984.

10. R. Huisgen, Angew. Chem., Int. Ed. Engl., 1963, 2, 565.

11. N. Abe, K. Odagiri, and A. Kakehi, J. Chem. Soc., Perkin Trans. 1, 1997, 2189. 
12. H. Fujii, K. Iwafuji, Y. Sawae, N. Abe, and A. Kakehi, Heterocycles, 2003, 59, 63.

13. Recent reviews see, N. Abe, Recent Res. Devel. Org. \& Bioorg. Chem., 2001, 4, 17; N. Abe, Trends in Heterocycl. Chem., 2001, 7, 25.

14. H. Okada, T. Akaki, Y. Oderaotoshi, S. Minakata, and M. Komatsu, Tetrahedron, 2003, 59, 197.

15. N. Abe, Y. Fukumoto, H. Fujii, and A. Kakehi, Heterocycles, 2002, 56, 171.

16. Chi-Rhi Wu and Paw-Wang Yang, Hua, Hsueh, 1977, 45; Chem. Abstr., 1980, 92, 94177n.

17. Spartan'02: W. J. Hehre, J. Yu, P. E. Klunzinger, and L. Lou, Wavefunction, Inc., CA (2002).

18. O. Tsuge, S. Kanemasa, S. Kuraoka, and S. Takenaka, Chem. Lett., 1984, 279.

19. O. Tsuge, S. Kanemasa, S. Kuraoka, and S. Takenaka, Chem. Lett., 1984, 281.

20. Y. Miki, H. Hachiken, S. Takemura, and M. Ikeda, Heterocycles, 1984, 22, 701.

21. N. Abe, Y. Fukazawa, Y. Hirai, T. Sakurai, K. Urushido, and A. Kakehi, Bull. Chem. Soc. Jpn., 1992, 65, 1784.

22. N. Abe, K. Odagiri, M. Otani, E. Fujinaga, H. Fujii, and A. Kakehi, J. Chem. Soc., Perkin Trans. 1, 1999, 1339. 